\title{
IS OBESITY A RISK FACTOR FOR FREE VASCULARIZED FIBULAR FLAP COMPLICATIONS?
}

\author{
A OBESIDADE É FATOR DE RISCO PARA COMPLICAÇÕES \\ DO RETALHO LIVRE DE FÍBULA VASCULARIZADA?
}

\author{
Raquel Bernardell lamaguchi ${ }^{1}$, Marco aurélo de Moraes ${ }^{1}$, Gustavo Bersani Silva ${ }^{1}$, alvaro Baik ChO $^{1}$, \\ Fernanda do Carmo IWASE ${ }^{1}$, Teng HSIANg WeI ${ }^{1}$, Marcelo Rosa de Rezende ${ }^{1}$, Rames MattaR JR ${ }^{1}$ \\ 1. Universidade de São Paulo, Faculdade de Medicina, Hospital das Clínicas (IOT/HCFMUSP), Instituto de Ortopedia e Traumatologia, Hand Surgery and Reconstructive Microsurgery Group, \\ São Paulo, SP, Brazil.
}

\section{ABSTRACT}

Objective: Although our knowledge of bone reconstruction through microsurgery has increased, the vascularized fibula flap remains one of the most difficult free flap reconstructions to perform, and complications remain a challenge. The incidence of obesity is increasing and is associated with higher rates of free flap complications, which can lead to disastrous results. Since there is no consensus in literature regarding the influence of obesity on free flap outcomes in orthopedic surgeries that require segmental bone reconstruction, the objective of this study was to determine whether obesity increases the risk of post-operative complications (Clavien-Dindo grade III) after free vascularized fibular flap surgery. Methods: A cohort study was conducted in all patients undergoing free flap limb reconstructions between July 2014 and July 2018. Patients were separated in two groups based on their body mass index (BMI): non-obese and obese $\left(\mathrm{BMl} \geq 30 \mathrm{~kg} / \mathrm{m}^{2}\right)$. Results: Twenty-three free vascularized fibular flaps were studied. The indications included trauma in 13 , tumors in 7 , and congenital pseudarthrosis of the tibia in 3. Obese patients were associated with an increase in surgical complications ( $p=0.038)$. During the final follow-up, consolidation was obtained in 17 patients (74\%). Conclusion: Obesity is a risk factor for complications in free vascularized fibular flap surgery. Level of evidence IV, original article.

Keywords: Microsurgery; Free tissue flaps; Tissue transplantation; Risk factors; Fibula.

\section{RESUMO}

Objetivo: Apesar do crescente conhecimento em reconstrução óssea por meio de microcirurgia, o retalho livre de fíbula vascularizada ainda permanece como uma das reconstruções mais difíceis de ser executada, e suas complicações ainda são um desafio. A incidência da obesidade tem aumentado e está associada a taxas mais altas de complicações de retalhos livres, o que pode levar a resultados desastrosos. Uma vez que não há consenso na literatura a respeito da influência da obesidade nos desfechos dos retalhos livre em cirurgias ortopédicas que requeiram reconstrução de segmento ósseo, o objetivo deste estudo foi avaliar se a obesidade aumenta o risco de complicações pós-operatórias (Clavien-Dindo grau III) após a cirurgia de retalho livre de fíbula vascularizada. Métodos: Foi realizado um estudo de coorte transversal, com a inclusão de todos os pacientes submetidos à reconstrução de membros com retalho livre de fíbula vascularizada, entre julho de 2014 e julho de 2018. Os pacientes foram separados em dois grupos, com base no índice de massa corporal: não obesos e obesos (no índice de massa corporal $\geq 30 \mathrm{~kg} / \mathrm{m}^{2}$ ). Resultados: Foram analisados 23 retalhos livres de fíbula vascularizada. As indicações foram trauma em 13 casos, tumor em sete e pseudoartrose congênita da tíbia em três. Pacientes obesos foram associados a aumento nas complicações cirúrgicas $(p=0,038)$. No final do acompanhamento, a consolidação óssea foi obtida em 17 pacientes (74\%). Conclusão: A obesidade é um fator de risco para complicações no retalho livre de fíbula vascularizada. Nível de evidência IV, artigo original.

Descritores: Microcirurgia. Retalhos de tecido biológico.Transplante de tecidos. Fatores de risco. Fíbula.

Citation: lamaguchi RB, Moraes MA, Silva GB, Cho AB, Iwase FC, Wei TH, Rezende MR, Mattar Jr R. Is obesity a risk factor for free vascularized fibular flap complications? Acta Ortop Bras. [online]. 2019;27(4):192-6. Available from URL: http://www.scielo.br/aob.

\section{INTRODUCTION}

Free vascularized fibular flap is a standard technique for reconstruction of complex and long defects in lower and upper limbs, especially in traumatic and oncologic defects.

Although, the crescent knowledge in bone reconstruction with microsurgery, the fibular flap still remains one of the most difficult free flaps and complications, including the loss of viability of the vascularized bone and pseudarthrosis, remains a challenge.
With the crescent obesity in world population, the concern about complications, associated with this comorbidity, is raising. Obesity is associated with higher rates of complications in free flaps surgery and the most common is postoperative infection, which can lead to disastrous results, including total free flap loss and amputation. ${ }^{1,2}$ Since there is no previous description in literature about the correlation of obesity with higher rates of complications in vascularized bone flaps, to our knowledge; the aim of this study it to compare

All authors declare no potential conflict of interest related to this article.

This work was performed at the Universidade de São Paulo, Faculdade de Medicina, Hospital das Clínicas (IOT/HCFMUSP).

Correspondence: Raquel Bernardelli lamaguchi. Rua Dr. Ovídio Pires de Campos, 333, São Paulo, SP, Brazil. 05403-010. rbiamaguchi@gmail.com

Article received in 12/09/2018, approved in 03/20/2019 
obese and non-obese patients, according tosurgical complications rates, in free vascularized fibular flaps in orthopaedic surgeries, that requires segmental bone reconstruction.

\section{MATERIALS AND METHODS}

All consecutive patients who received a free vascularized fibular flap for upper and lower limb reconstruction forsegmental bone reconstructionat our institution, from July 2014 through July 2017, were included in a cohort study, following the strobe guidelines. No patient was excluded; informed consent was obtained from all individual participants included in the study and the minimal follow-up of one year. The study was approved by the Ethics Committee (Protocol number 42679515.2.0000.0068). Patients were separated in two groups, based on their BMl, calculated by dividing the weight in kilograms $(\mathrm{kg})$ by height in meters $(\mathrm{m})$ squared: non-obese $(\mathrm{BMl}<$ $\left.30 \mathrm{~kg} / \mathrm{m}^{2}\right)$ and obese $\left(\mathrm{BMl} \geq 30 \mathrm{~kg} / \mathrm{m}^{2}\right)$ and according to the World Health Organization (WHO) definition of obesity.

Patient demographics (age, gender and comorbidities), location and size of bone defect, operative technique, including the type of fixation of bone flap, and intraoperative or postoperative surgical complications were studied. The ischemia time of the free flap was studied, which was defined as the time between the section of the pedicle in the donor area and the release of clamps of the artery and at least 1 vein (in cases in which more than 1 vein was anastomosed) and perfusion of the flap was observed.

The surgical complications withgrade III (complications requiring surgical intervention) of Clavien-Dindo classification, ${ }^{3,4}$ observed were: dehiscence, partial or total skin island flap loss, thrombosis with absence of vascular flow in vascularized fibula with anastomoses revision and infection.

Consolidation was established on standard clinical and radiological parameters in consecutive radiographs and was not considered a Clavien-Dindo complication as it is a late complication in follow-up of vascularized fibular flap. It was studied the occurrence of pseudarthrosis and need for further surgeries to obtain consolidation. After consolidation, it was analyzed the final functional result and the use of orthotic or ambulatory aid were assessed.

\section{Statistical Analysis}

Statistical analyses were performed with SPSS 20.0 (SPSS Inc $\AA_{\text {, }}$ Chicago, IL, EUA). All tests were two-tailed, and statistical significance was defined as $p<0.05$. Qualitative data were analyzed by Pearson chi-square test or Fisher exact test. Mann-Whitney U-test was used for quantitative nonparametric data. Multinomial logistic regression was then conducted on the variables that were significant by univariate analysis or with a P-value $<0.20$. The backward algorithm was used.

\section{RESULTS}

A total of 23 free vascularized fibular flaps were performed in 23 patients. Of these, 14 patients were male and 9 female. The indications for bone reconstruction were defects cause by: trauma in 13 patients, tumor in 7 patients and congenital pseudarthrosis of the tibia in three patients. (Figure 1) The type of bone tumor were: giant cell tumor in three cases, osteosarcoma in two cases, B-cell lymphoma in one case and adamantinoma in one case. (Figure 2)

Patients were divided in two groups according to the BMI: 18 patients were non-obese and 5 patients obese $\left(\mathrm{BMI} \geq 30 \mathrm{~kg} / \mathrm{m}^{2}\right)$. Age, indications, wound location and size of bone defect were similar in both groups (obese versus non-obese).

The most common anatomical area of bone lesion was leg in eight cases, followed by forearm in six cases. (Figure 3)

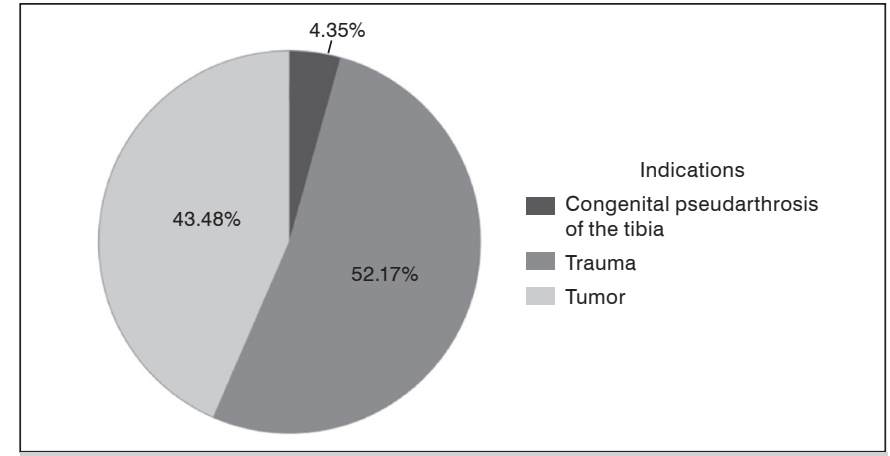

Figure 1. Indications of free vascularized fibular flap.

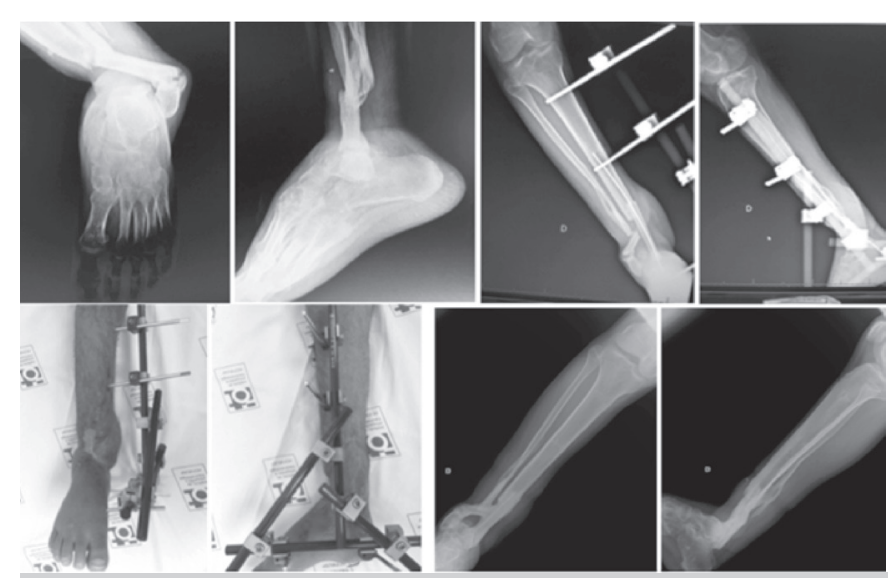

Figure 2. Male, 30 years old, motorcycle accident with open fracture of the distal leg with chronic traumatic wound. Submitted to free vascularized fibular flap for bone and soft tissue reconstruction. Final results with bone consolidation and satisfactory ambulation without bracing or crutches after two years.

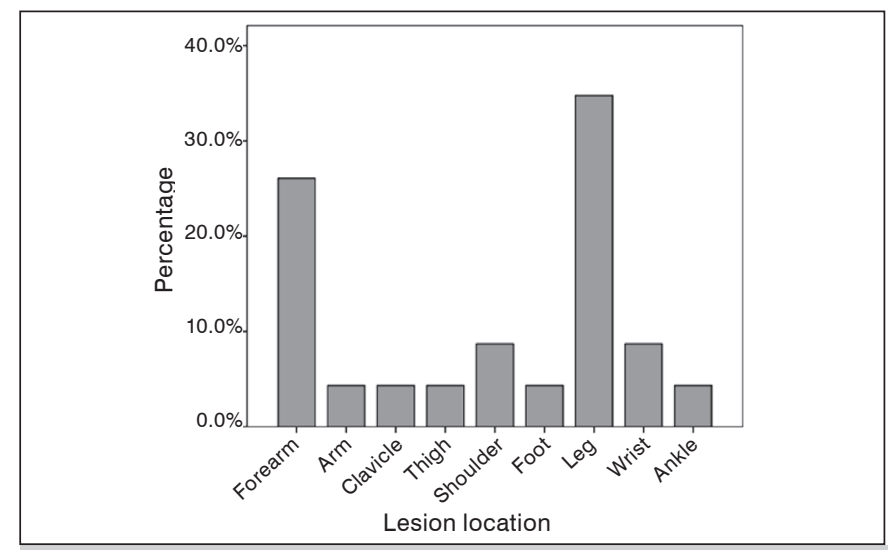

Figure 3. Description of anatomical area of the bone lesion.

The method of fixation was: plate and screw for 11 patients, K-wire and cast for 3 patients and a combination of external fixator, screw and/or K-wire for 9 patients.

The average intraoperative ischemia time of free vascularized fibular flap was 133,2 minutes (SD 42,8) for non-obese patients and 195,6 minutes $(S D 71,4)$ for obese patients $(p=0,08)$.

Twelve patients had surgical complications, including: 1 dehiscence, that required a local flap for coverage); 1 loss of skin island that required a local flap for coverage of fibular flap; 2 cases of post-operative infection that required surgery and treatment with 
antibiotics, with complete resolution of infection, but one case lost the skin island flap and the other had pseudarthrosis of fibular flap, that was submitted to bone graft and plate with screw fixation, with final consolidation; 8 cases had signs of vascular compromise of the skin island and were submitted to reexploration, of these, two cases had thrombosis of the anastomoses and were successfully revised; two cases lost only the skin island flap without vascular compromise; one patient required hematoma drainage without thrombosis; and 3 patients had thrombosis with absence of flow in vascularized fibula, one of these patients had congenital pseudarthrosis of the tibia, the second patient had a traumatic defect of the foot and the other was a reconstruction after excision of humeral tumor. The avascular fibula was maintained after complete debridement of soft tissue. The second patient was submitted to a successful anterolateral thigh flap for coverage of the foot, but maintained a post-operative infection and at last was submitted to a Chopart amputation. Seven patients had comorbidities, including five smokers patients and comorbidities were not risk factors for complications $(p=0,86)$. (Table 1)

At final follow-up consolidation was obtained in 17 patients (74\%). Two patients had pseudarthrosis prior to final consolidation and were submitted to revision of fixation, one of these to plate and screw fixation associated to bone autograft and the other to llizarovexternal fixator. Among six patients without final consolidation, one patient had consolidation in proximal fixation of free vascularized fibular flap with distal pseudarthrosis but was walking with a cane; one patient had tumor recurrence and was submitted to shoulder disarticulation; and the remaining four patients, were submitted to amputation (3 transtibial and one Chopart level). In regard to gait evaluation, of the 11 patients submitted to free vascularized fibular flap transferred for the lower limb: four were submitted to amputation, five patients were walking with crutches, two patients with a cane and three patients without aid. The average defect size of patients with surgical complications was $9,7 \mathrm{~cm}$ and patients without complications was 12,5 , no statistical difference was observed $(p=0,163)$.

The type of fixation with plate and screw compared to other methods, did not influenced the results, regarding the surgical complications $(p=0,855)$ or consolidation rates $(p=0,640)$. Obesity did not influenced the complication rates $(p=1,0)$.

All obese patients had complications (grade III Clavien-Dindo) when compared with non-obese patients (44\%) and obesitywas significantly associated with an increase in surgical complications rates of grade III Clavien-Dindo classification $(p=0,038)$. (Figure 4)

\begin{tabular}{|c|c|c|c|c|c|c|c|c|c|c|c|}
\hline Patient & Age & Sex & Indication & Comorbidities & $\begin{array}{l}\text { Defect } \\
\text { location }\end{array}$ & $\begin{array}{l}\text { Size } \\
\text { defect } \\
(\mathrm{mm})\end{array}$ & $\begin{array}{c}\text { BMI (kg/ } \\
\left.\mathrm{m}^{2}\right)\end{array}$ & Complications & Type of fixation & $\begin{array}{c}\text { Consolidation } \\
(\mathrm{Y} / \mathrm{N})\end{array}$ & $\begin{array}{c}\text { Deambulation } \\
(\mathrm{Y} / \mathrm{N}) / \\
\text { Amputation }\end{array}$ \\
\hline$\# 1$ & 9 & $\mathrm{~F}$ & Tumor & & Shoulder & 221 & 19,37 & & Plate and screws & $\mathrm{Y}$ & $\mathrm{N} / \mathrm{A}$ \\
\hline \#2 & 17 & $F$ & Tumor & & Leg & 103 & 18,83 & & Plate and screws & $\mathrm{Y}$ & $\mathrm{Y}$ \\
\hline \#3 & 51 & M & Tumor & & $\begin{array}{l}\text { Leg and } \\
\text { Ankle }\end{array}$ & 232 & 26,93 & & $\begin{array}{l}\text { External fixator } \\
\text { and screws }\end{array}$ & $\mathrm{N}$ & $Y$ - cane \\
\hline \#4 & 31 & M & Trauma & Smoking; Diabetes & Leg & 68 & 19,38 & & $\begin{array}{l}\text { External fixator } \\
\text { and K-wires }\end{array}$ & Y & Y \\
\hline \#5 & 42 & M & Trauma & Smoking & Leg & 140 & 25,71 & & $\begin{array}{l}\text { External fixator } \\
\text { and K-wires }\end{array}$ & $\mathrm{Y}$ & Y - crutches \\
\hline \#6 & 45 & M & Tumor & & Arm & 56 & 30,46 & $\begin{array}{l}\text { Anastomoses revision; } \\
\text { total flap loss }\end{array}$ & Plate and screws & $\mathrm{N}$ & $\mathrm{N} / \mathrm{A}$ \\
\hline \#7 & 23 & M & Trauma & & Thigh & 232 & 20,62 & Anastomoses Revision & $\begin{array}{l}\text { External fixator } \\
\text { and K-wires }\end{array}$ & $\mathrm{N}$ & Amputation \\
\hline \#8 & 23 & M & Trauma & Smoking & Forearm & 93 & 24,22 & $\begin{array}{l}\text { Anastomoses Revision; } \\
\text { Skin island flap loss }\end{array}$ & $\mathrm{K}$-wires & $\mathrm{Y}$ & N/A \\
\hline$\# 9$ & 2 & $\mathrm{~F}$ & CPT & & Leg & 48 & 15,00 & & $\begin{array}{l}\text { External fixator } \\
\text { and K-wires }\end{array}$ & Y & Y \\
\hline$\# 10$ & 36 & M & Trauma & Smoking & Clavicle & 73 & 25,22 & $\begin{array}{l}\text { Dehiscence; Local } \\
\text { flap for coverage }\end{array}$ & Plate and screws & $\mathrm{Y}$ & N/A \\
\hline$\# 11$ & 10 & $\mathrm{~F}$ & Tumor & & Shoulder & 158 & 15,48 & $\begin{array}{l}\text { Anastomoses Revision; } \\
\text { Skin island flap loss }\end{array}$ & Plate and screws & $\mathrm{Y}$ & $\mathrm{N} / \mathrm{A}$ \\
\hline \#12 & 45 & $\mathrm{~F}$ & Trauma & $\begin{array}{c}\text { Smoking; Hypertension; } \\
\text { Hypothyroidism }\end{array}$ & Wrist & 69 & 40,40 & Anastomoses Revision & K-wires & Y & $\mathrm{N} / \mathrm{A}$ \\
\hline$\# 13$ & 24 & $\mathrm{~F}$ & Trauma & & Leg & 123 & 21,60 & $\begin{array}{l}\text { Partial Flap Loss; Local } \\
\text { flap for coverage }\end{array}$ & $\begin{array}{l}\text { External fixator } \\
\text { and K-wires }\end{array}$ & $\mathrm{Y}$ & Y \\
\hline$\# 14$ & 57 & $\mathrm{~F}$ & Tumor & Diabetes; Hypertension & Wrist & 90 & 27,92 & & Plate and screws & $\mathrm{Y}$ & $\mathrm{N} / \mathrm{A}$ \\
\hline$\# 15$ & 26 & $\mathrm{M}$ & Tumor & Cocaine use & Forearm & 124 & 20,16 & & Plate and screws & $\mathrm{Y}$ & $\mathrm{N} / \mathrm{A}$ \\
\hline$\# 16$ & 3 & M & CPT & & Leg & 80 & 19,38 & $\begin{array}{l}\text { Anastomoses revision; } \\
\text { Total Flap Loss }\end{array}$ & $\begin{array}{l}\text { External fixator } \\
\text { and K-wires }\end{array}$ & $\mathrm{N}$ & Amputation \\
\hline \#17 & 28 & M & Trauma & & Forearm & 86 & 30,31 & $\begin{array}{l}\text { Post-operative infection; } \\
\text { Skin island flap loss }\end{array}$ & $\mathrm{K}$-wires & $\mathrm{Y}$ & $\mathrm{N} / \mathrm{A}$ \\
\hline$\# 18$ & 29 & $\mathrm{~F}$ & Tumor & & Forearm & 111 & 23,78 & & Plate and screws & $Y$ & N/A \\
\hline$\# 19$ & 26 & $\mathrm{~F}$ & Trauma & & Forearm & 142 & 33,80 & Post-operative infection & Plate and screws & $\mathrm{Y}$ & $\mathrm{N} / \mathrm{A}$ \\
\hline \#20 & 10 & M & СРT & & Leg & 82 & 15,03 & & $\begin{array}{l}\text { External fixator } \\
\text { and screws }\end{array}$ & $\mathrm{N}$ & Amputation \\
\hline \#21 & 40 & M & Trauma & & Foot & 57 & 27,16 & $\begin{array}{l}\text { Anastomoses revision; } \\
\text { Total flap loss }\end{array}$ & Plate and screws & $\mathrm{N}$ & Amputation \\
\hline \#22 & 38 & M & Trauma & & Ankle & 79 & 22,94 & & $\begin{array}{c}\text { External fixator, } \\
\text { screws and K-wires }\end{array}$ & $\mathrm{Y}$ & Y \\
\hline \#23 & 31 & M & Trauma & & Forearm & 43 & 30,02 & $\begin{array}{c}\text { Anastomoses } \\
\text { Revision; Hematoma drainage }\end{array}$ & Plate and screws & $\mathrm{Y}$ & $\mathrm{N} / \mathrm{A}$ \\
\hline
\end{tabular}




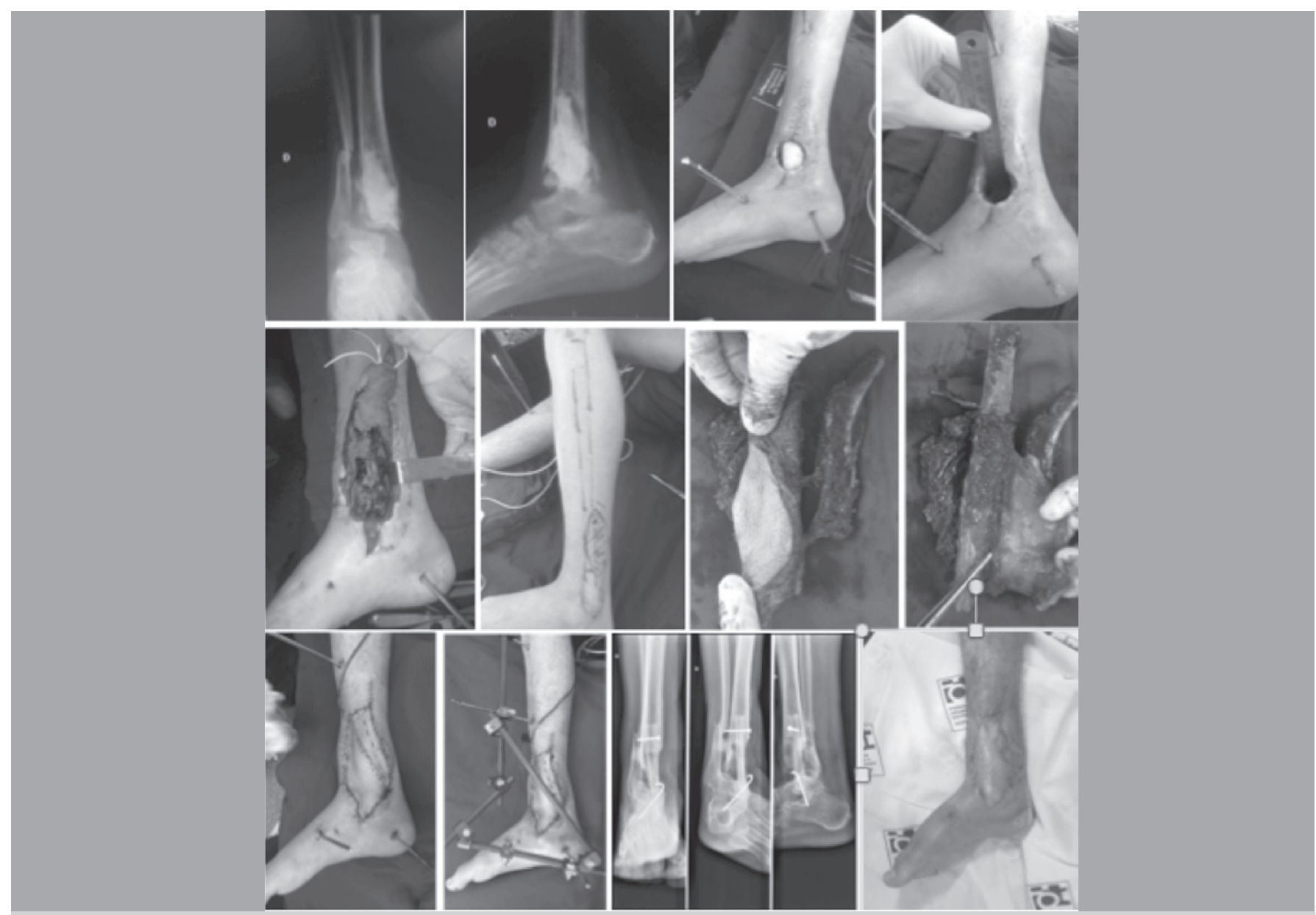

Figure 4. Male, 38 years, postoperative infection after internal fixation after an ankle sprain, forwarded with bone and soft tissue wound of the ankle. Submitted to free vascularized fibular flap for bone and soft tissue reconstruction. Final result after 15 months, achieving satisfactory ambulation, without aid.

\section{DISCUSSION}

The free vascularized fibular flap is a reliable technique for reconstruction of bone defects, usually larger than $6 \mathrm{~cm}$, and indications includes: limb reconstruction after tumor, trauma, infection and congenital deformities. ${ }^{5,6,7}$ Taylor et al 4 describes 38 free vascularized fibular flaps for tibial reconstruction, observing that, stress fractures before consolidation, occurs in most cases and obtain an overall success rate of $95 \%$, with vascularized bone flaps. The complications described to vascularized fibular flaps includes: thrombosis of vessels anastomoses, infection, pseudarthrosis and inadequate graft hypertrophy, and can lead to limb amputation in these severe cases. ${ }^{8}$

The type of bone fixation of the vascularized fibular flap varies according to the recipient site, location in long bones defects, age of patients and the preference of the surgeon. Inadequate fixation is one of the causes of pseudarthrosis, ${ }^{9}$ in our study, we could not observe difference in consolidation rates or surgical complications with different types of fixation, and bone union was obtained in $74 \%$ of cases, similar to literature..$^{10,11}$

Obesity is a common risk factor studied for free flaps complications. ${ }^{12,13}$ For our knowledge, there is no description of obesity influencing specifically vascularized bone flaps. Obesity may lead to difficulties during harvest and inset of free flap, prolonging operative time, increasing the risk of post-operative deep surgical site infection, ${ }^{14}$ intraoperative total blood loss and free flap loss. ${ }^{15} \mathrm{We}$ observed that obese patients, with BMI $>30 \mathrm{~kg} / \mathrm{m}^{2}$, had an increase in complications rates, with statistically significant difference. The average intraoperative ischemia time of free vascularized fibular flap was longer in obese patients, this fact may be justified by the greater difficulty in the surgical access no neurovascular structures and in the donor and recipient area dissection, although it was not statistically significant wich can be justified by the number of patients included in this study. When performing surgeries in obese patients, they should be aware of the increased risk.

Although a high rate of complications, our overall success rates are similar to those in the literature, with $13 \%$ total flap loss.

The limitation of the study is the small number of patients, which can lead to a type II error. Another important bias is the choice of bone fixation that can influence in consolidation results.

\section{CONCLUSION}

Obesity is a risk factor for complication in free vascularized fibular flap.

AUTHORS' CONTRIBUTIONS: Each author contributed individually and significantly to this paper. RBI (0000-0002-8965-5147) ${ }^{\star}$ : redação do artigo, estatística,revisão,conceito intelectual do artigo, realização das cirurgias e confecção de todo projeto de pesquisa; MAM (0000-0002-8165-115X)*: Captação de dados e revisão; GBS (0000-0002-8684-4479)*: realização da cirurgias e revisão; ABC (0000-0002-3099-4750)*: realização da cirurgias e revisão FCI (00000001-9616-4381)*: realização das cirurgias e revisão; THW (0000-0001-6219-0047)*: revisão e conceito intelectual do artigo; MRR (0000-0003-3441-8117)*: revisão e conceito intelectual do artigo; RMJ (0000-0003-4202-4652)*: revisão e conceito intelectual do artigo. *ORCID (Open Researcher and Contributor ID). 


\section{REFERENCES}

1. Cleveland EC, Fischer JP, Nelson JA, Wink JD, Levin LS, Kovach SJ. Free flap lower extremity reconstruction in the obese population: Does weight matter. J Reconstr Microsurg. 2014;30(4):263-70.

2. Khouri RK, Cooley BC, Kunselman AR, Landis JR, Yeramian P, Ingram D, et al. A prospective study of microvascular free-flap surgery and outcome. Plast Reconstr Surg. 1998;102(3):711-21.

3. Clavien PA, Barkun J, Oliveira ML, Vauthey N, Dindo D, Schulick RD, et al. The Clavien-Dindo classification of surgical complications. Five-year experience. Ann Surg. 2009;250(2):187-96.

4. Moreira LF, Pessôa MCM, Mattana DS, Schmitz FF, Volkweiss BS, Antoniazz $\mathrm{JL}$, et al. Cultural adaptation and the Clavien-Dindo surgical complications classification translated to Brazilian Portuguese. Rev Col Bras Cir. 2016;43(3):141-8.

5. Taylor GI, Corlett RJ, Ashton MW. The Evolution of Free Vascularized Bone Transfer: A 40-Year Experience. Plast Reconstr Surg. 2016;137(4):1292-305.

6. Repo JP, Sommarhem A, Roine RP, Sintonen H, Halonen T, Tukiainen E. Free vascularized fibular graft is reliable in upper extremity long-bone reconstruction with good long-term outcomes. J Reconstr Microsurg. 2016;32(7):513-9.

7. lamaguchi RB, Fucs PMMB, Costa AC, Chakkour I. Vascularized fibular graft for the treatment of congenital pseudarthrosis of the tibia: long-term complications in the donor leg. Int Orthop. 2011;35(7):1065-70.

8. Bumbasirevic M, Stevanovic M, Bumbasirevic V, Lesic A, Atkinson HDE. Free vascularized fibular grafts in orthopaedics. Int Orthop. 2014;38(6):1277-82.
9. Beris AE, Lykissas MG, Korompilias AV, Vekris MD, Mitsionis GI, Malizos KN, et al. Vascularized fibula transfer for lower limb reconstruction. Microsurgery. 2011;31(3):205-11.

10. Zaretski A, Amir A, Meller I, Leshem D, Kollender Y, Barnea Y, et al. Free fibula long bone reconstruction in orthopaedic oncology: A surgical algorithm for reconstructive options. Plast Reconstr Surg. 2004;113(7): 1989-2000.

11. Belt PJ, Dickinson IC, Theile DRB. Vascularized free fibular flap in bone resection and reconstruction. Br J Plast Surg. 2005;58(4):425-30.

12. Shin JY, Roh SG, Lee NH, Yang KM. Is obesity a predisposing factor for free flap failure and complications? Comparison between breast and nonbreast reconstruction: Systematic review and meta-analysis. Medicine (Baltimore). 2016;95(26):e4072.

13. De la Garza G, Militsakh O, Panwar A, Galloway TL, Joergesen JB, Ledgerwood LG, et al. Obesity and perioperative complications in head and neck free tissue reconstruction. Head Neck. 2016;38(Suppl 1):E1188-91.

14. Namba RS, Inacio MC, Paxton EW. Risk factor associated with surgical site infection in 30,491 primary total hip replacements. J Bone Joint Surg Br. 2012;94(10):1330-8.

15. Chang DW, Wang B, Robb GL, Reece GP, Miller MJ, Evans GR, et al. Effect of obesity on flap and donor-site complications in free transverse rectus abdominis myocutaneous flap breast reconstruction. Plast Reconstr Surg. 2000;105(5):1640-8. 